DOI: http://dx.doi.org/10.33846/hn40602

http://heanoti.com/index.php/hn

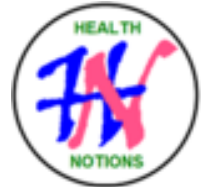

RESEARCH ARTICLE

URL of this article: http://heanoti.com/index.php/hn/article/view/hn40602

\title{
The Influence of Immunization Counseling Module Using Stickers on Toddler's Mother Behavior about Advanced Immunization (Booster)
}

\author{
Nurhayati $^{1(\mathrm{CA})}$, Sudiyati ${ }^{2}$, Erlin Puspita ${ }^{3}$, Siti Rahmadani ${ }^{4}$ \\ ${ }^{1(\mathrm{CA})}$ Poltekkes Kemenkes Jakarta I, Indonesia; nurhayatisamlawi@ gmail.com (Corresponding Author) \\ ${ }^{2}$ Poltekkes Kemenkes Jakarta I, Indonesia \\ ${ }^{3}$ Poltekkes Kemenkes Jakarta I, Indonesia \\ ${ }^{4}$ Poltekkes Kemenkes Jakarta I, Indonesia; aksarahmadani@gmail.com
}

\begin{abstract}
In Indonesia, the coverage of the immunization is still low and the incidence of diseases caused by not having DPT-HB-Hib immunization is still high. The purpose of this study was to determine the influence of immunization counseling using stickers on toddler's mother behavior about advanced immunization (booster). The design of this study was a pretest and post test with a control group. The population in this study were all mothers who had toddlers aged 12-24 months in the integrated health service center area of Depok City with a sample of 60 mothers divided into 2 groups. The results showed that there were differences in knowledge (pvalue $=0.011)$ and actions ( $\mathrm{p}$-value $=0.036$ ) in the intervention and the control group after immunization counseling using a counseling module and stickers. Based on the results, there is influence of knowledge on maternal behavior about advanced immunization in toddlers.
\end{abstract}

Keywords: advanced immunization; maternal behavior; counseling

\section{INTRODUCTION}

Immunization is an attempt to actively induce or increase a person's immunity to a disease, so that if one day is exposed to the disease it will not hurt or only experience mild illness. Immunization is an official program of the Indonesian government as stipulated in Regulation of the Minister of Health of the Republic of Indonesia Number 42 of 2013 concerning the delivery of immunizations. ${ }^{(1)}$ Immunization consists of compulsory immunization and choice immunization. Mandatory immunization is an immunization that is required by the government for someone in accordance with their needs in order to protect the person concerned and the surrounding community from certain infectious diseases.

In the type of immunization that requires a repeat (booster) or referred to as advanced immunization, in addition to being given according to schedule also requires health education efforts so that mothers of toddlers understand the importance of these advanced immunization efforts; which includes advanced immunization in infants is DPT-HB-Hib vaccine at the age of 18 months and measles at 24 months. Based on a review from the WHO / SEARO Regional Review Meeting on Immunization in New Delhi and the Indonesian Technical Advisory Group Immunization (ITAGI) Expert Advisory Committee (ITAGI) in 2010, recommended that the HIB vaccine be integrated into national immunizations to reduce morbidity and infant mortality and toddlers due to pneumonia and meningitis. ${ }^{(1-3)}$

Determination of the pentavalent immunization program is motivated by the presence of pneumonia which is the biggest cause of death in children, $23 \%$ of serious pneumonia in children is caused by haemophillus influenzae type $\mathrm{b}$ (Hib). One factor that needs to be considered in the effectiveness of immunization is adherence to the immunization schedule. If the mother is not compliant in immunizing her baby, it will greatly affect the body's immunity and vulnerability to an illness. So expect babies to get immunizations on time to protect them from various dangerous diseases ${ }^{(4)}$.

Vaccination is important for public health. The immunization program is one of the priorities in health development because it can prevent morbidity, death and disability. Bacterial meningitis is generally very severe 
and can cause brain damage and death. CDC report (2000), Hib can cause meningitis (50\%), cellulitis (6\%), epiglotitis $(17 \%)$, osteomyelitis $(2 \%)$, pneumonia $(15 \%)$, bacteremia $(2 \%)$, and arthritis $(8 \%) .{ }^{(5)}$ While other causes are pneumococcus, staphilococcus, streptococcus, viruses and fungi. Before the Hib vaccination era, global Hib disease caused by children (WHO estimation) caused: 3 million children to suffer from serious illnesses per year, death to $\geq 400,000$ children, the number 1 cause of death in the world.

\section{METHODS}

This type of research was a quasi experimental, using pretest and post test with a control group design. In this study two groups were used, the intervention group was given booklet counseling and immunization stickers, the control group was given health education, then it was seen whether the two groups brought their toddlers to come to the integrated health service center to be immunized (pentavalent-DPT, HB, Hib) according to the schedule set. The sample size was 60 .

\section{RESULT}

Table 1. Distribution of respondents characteristics

\begin{tabular}{ccccccc}
\hline \multirow{2}{*}{ Characteristics } & \multicolumn{9}{c}{ Group } \\
\cline { 2 - 7 } & \multicolumn{2}{c}{ Intervention } & \multicolumn{2}{c}{ Control } & \multicolumn{2}{c}{ Total } \\
\cline { 2 - 7 } & $\mathrm{n}$ & $\%$ & $\mathrm{n}$ & $\%$ & $\mathrm{n}$ & $\%$ \\
\hline Age & & & & & & \\
<29 years old & 24 & 67 & 16 & 67 & 40 & 67 \\
$\geq$ 29years old & 12 & 33 & 8 & 33 & 20 & 33 \\
\hline Education & & & & & & \\
Low & 8 & 28 & 7 & 23 & 15 & 25 \\
High & 21 & 72 & 24 & 77 & 45 & 75 \\
\hline Income RT & & & & & & \\
<UMR & 13 & 43.3 & 10 & 33.3 & 23 & 43.3 \\
$\geq$ UMR & 17 & 56.7 & 20 & 66.7 & 37 & 61.6 \\
\hline & & & & & & \\
Numbers of children & & & & & & \\
1 & 13 & 46 & 15 & 47 & 28 & 47 \\
$>1$ & 15 & 54 & 17 & 53 & 32 & 53 \\
\hline
\end{tabular}

From 60 toddler's mothers who were research respondents and divided into 2 groups, namely the intervention group and the control group. The characteristics of the intervention group were known that the majority of mothers aged over 29 years were 12 respondents (33\%). In terms of education, the majority of mothers with tertiary education (high school and above) were 21 respondents (72\%) and had an income above the UMR of 17 respondents (56.7\%), while if seen from the number of children, mothers who had children more than 1 as many as 15 respondents $(54 \%)$.

Table 2. Differences in knowledge, attitudes and actions of mothers about advanced immunization in the intervention and control group after counseling

\begin{tabular}{lccc}
\hline Variable & Mean rank & $p$ & $\mathrm{Z}$ \\
\hline Knowledge & & & \\
--Intervention & 36.12 & 0.011 & -2.539 \\
--Control & 24.88 & & \\
\hline Attitude & & & \\
--Intervention & 32.97 & 0.263 & -1.120 \\
--Control & 28.03 & & \\
\hline Action & & & \\
--Intervention & 34.82 & 0.036 & -2.093 \\
--Control & 26.18 & & \\
\hline
\end{tabular}


Based on the results of the Man Whitney test after treatment on the knowledge variable, the p-value of $0.011(<0.05)$ shows that there was a significant difference between maternal knowledge about immunization after being given further immunization counseling using booklets and stickers between the two groups. In the mother's attitude variable regarding further immunization, it was obtained a p-value of $0.2631(>0.05)$. In the action variable, the p-value of $0.036(<0.05)$ shows that there was a significant difference between maternal actions regarding continued immunization after being given advanced immunization counseling using booklets and stickers.

\section{DISCUSSION}

\section{Knowledge}

Based on the results, there is a significant difference between the mother's knowledge about immunization after being given further immunization counseling using booklets and stickers. According to Notoatmodjo $^{(6)}$, the factors that influence a person's knowledge include education, experience, information, cultural environment, age and socio-economy. These factors will be closely related and affect one's knowledge. A person's knowledge can be increased by being given an education through the media.

Booklet media and stickers become one of the media used to increase one's knowledge which contains brief and clear material to facilitate understanding of advanced immunization in toddlers. The booklet is designed in the form of a book that contains more information so that the mother can simply listen to what is conveyed without needing to record all the material presented. Sticker media are given to respondents when they are going home after getting counseling, stickers are intended as a reminder to respondents of the schedule of giving advanced immunizations (booster) to children. Stickers are information media in the form of small sheets of paper or plastic with easy-to-understand language whose use is affixed.

To reach their goals as fully as possible by visual tools, the images must meet certain requirements such as simplicity of images, images must be true, interesting, clear, and stimulate interest to view them and clarify the meaning of what is described. The booklet media is effective in increasing respondents' knowledge about advanced immunization. According to Hapsari's research entitled Effectiveness of communication of natural children's booklet media as a medium for delivering gentle birth service messages stating that $74 \%$ of 100 respondents rated the booklet as having effective communication as a messenger. Health education delivered using media such as booklets or stickers can influence one's knowledge in accordance with the objectives of the health education.

\section{Attitude}

Based on the results, there is no significant difference in maternal attitudes between the intervention and control groups after treatment. Changes in attitude are influenced by the extent to which the contents of communication or stimuli are considered, understood and accepted so as to give a positive response. Besides forming attitudes is not easy because it can not be separated from the factors that affect respondents, such as personal experience, culture, mass media, and emotional factors in individuals. Insignificant increase in respondents' attitudes in accordance with Azwar's ${ }^{(7)}$ statement, which is a message intended to change attitudes subtly, is usually more successful than messages that appear to be trying to manipulate respondents. This is because humans tend not to be manipulated, so that if the respondent is aware of an effort that intentionally wants to change human attitudes, then humans will try to reject it. This problem is generally often experienced by respondents as extension participants.

\section{Action}

Based on the results, there is significant differences between maternal actions regarding continued immunization after being given advanced immunization counseling using booklets and stickers. Psychology views human behavior as a simple or complex reaction. Behavior can be interpreted as a person's response to external stimuli that can take the form of internal responses such as knowledge and attitudes and external responses such as actions. Good actions will most likely give a person's perspective to behave well in terms of immunizing their offspring. Besides being used as a tool to clarify media, it can also function to give a deep impression. Therefore the media can influence a person's behavior into a positive direction, because it is based on respondents' knowledge and experience. Behavior that is based on knowledge will last longer than behavior that is not based on knowledge.

Behavioral correlations are strongly influenced by the function of individual characteristics and environmental factors. Individual characteristics that include variables of nature, personality and attitudes that interact with each other and then interact with environmental factors in determining behavior. Environmental 
factors have a large power in determining behavior, sometimes even greater strength than individual characteristics.

\section{CONCLUSION}

Research on the effect of immunization counseling using stickers on maternal behavior about advanced immunization (booster) in toddlers can be concluded that there are differences in knowledge and actions in the intervention group and the control group before and after treatment.

\section{REFERENCES}

1. MoH-RI. Regulation of the Minister of Health of the Republic of Indonesia Number 42 of 2013 concerning the delivery of immunizations. Jakarta: MoH-RI; 2013.

2. MoH-RI. Immunization Training Module for community health center staff (Modul Pelatihan Imunisasi bagi petugas Puskesmas). Jakarta: MoH-RI; 2013.

3. MoH-RI. Technical Guidance on Introducing DTP-HB-Hib (Pentavalent) Immunization in Infants and Implementation of Advanced Immunization in Toddlers (Petunjuk Teknis Introduksi Imunisasi DTP-HBHib (Pentavalen) Pada Bayi dan Pelaksanaan Imunisasi Lanjutan Pada Anak Balita). Jakarta: MoH-RI; 2013.

4. MoH-RI. Immunization Technical Guidelines at Community Health Center Level (Pedoman Teknis Imunisasi Tingkat Puskesmas). Jakarta: MoH-RI; 2005.

5. Sukoharjo District Health Office. Health Profile of Sukoharjo District (Profil Kesehatan Kabupaten Sukoharjo). Sukoharjo: Sukoharjo District Health Office; 2013.

6. Notoatmodjo. Health Education and Behavioral Sciences (Pendidikan Kesehatan dan Ilmu Perilaku, Jakarta: Rineka Cipta; 2003.

7. Azwar S. Human Attitudes, Theories and Measurements (Sikap Manusia, Teori dan Pengukurannya). Yogyakarta: Pustaka Pelajar; 2003. 